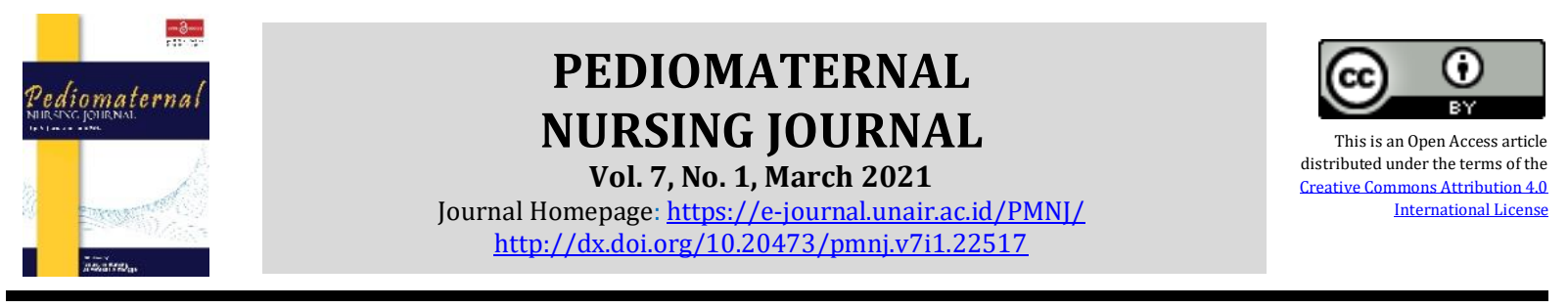

Original Research

\title{
Perception and Prevalence of Bullying Among Junior High School Students of Biliran Province State University
}

\author{
Jovy Dia R. Saniel (iD), Charlotte C. Opeña, Joice Balondo Balondo, Allyza Mariz B. \\ Bunda, Liezl B. Tambis
}

Maternity and Pediatric Nursing Department, Faculty of Nursing, Universitas Airlangga, Surabaya, Indonesia

\author{
ARTICLE HISTORY \\ Received: October 08, 2020 \\ Accepted: April 11, 2021 \\ Published: July 18, 2021 \\ KEYWORDS \\ Bullying; prevalence; \\ perception

\section{CORRESPONDING AUTHOR} \\ Jovy Dia R. Saniel \\ ardia8187@gmail.com \\ Biliran State University- \\ School of Nursing and Health \\ Sciences-Main Campus, \\ Naval, Biliran, Philippines
}

\begin{abstract}
Introduction: A school is where a student learns and molds into the desired individual but sometimes, a place where the famous and beautiful are honored and respected while the poor little ones are experience bullying. This study aims to determine the perceptions and prevalence of bullying to design a plan addressing issues on students' predicaments in Biliran Province State University (BiPSU).

Methods: The researchers made use of the Statistical Package for the Social Sciences (SPSS)-Descriptive Statistics' frequency, percentile and central tendency, where variables as to profile, perception and prevalence of bullying among secondary students are statistically analyzed.
\end{abstract}

Results: Students' perception of bullying is significant than its prevalence. Students have increased knowledge and awareness of bullying. However, though less notable than the perception, the pervasiveness of bullying is still considerable.

Conclusion: The majority of the respondents have not experienced bullying. Students think that bullying at school happens once or twice a term. Student's perception of bullying is more eminent than its prevalence. These pervasion results are meaningful because students' reflection in bullying is distinguished.

Saniel, J, D, R., Opeña, C, C., Balondo, J, B., et al. (2021). Perception and Prevalence of Bullying Among Junior High School Students of Biliran Province State University. Pediomaternal Nurs. J., 7(1), 40-46. Doi: http://dx.doi.org/10.20473/pmnj.v7i1.22517

\section{INTRODUCTION}

Bullying is alarming among youths. A recent survey reveals 1,965 students in seventh through twelfth grades, accounting for 48 percent $(48 \%)$, were harassed in some way (Anderson, 2011). Since many bullying cases include violent actions intended to create fear (name-calling; physical attacks; acts of humiliation, denigration, and mistreatment), bullying can cause traumatic stress responses. With these acts of bullying being continuous and going unnoticed, many children who experienced bullying develop 
Table 1. Profile of the Respondents

\begin{tabular}{|c|c|c|}
\hline Profile Variables & $f$ & $\%$ \\
\hline \multicolumn{3}{|l|}{ Age } \\
\hline 12 & 3 & 2.0 \\
\hline 13 & 50 & 33.3 \\
\hline 14 & 28 & 18.7 \\
\hline 15 & 28 & 18.7 \\
\hline 16 & 34 & 22.7 \\
\hline 17 & 7 & 4.7 \\
\hline \multicolumn{3}{|l|}{ Sex } \\
\hline Boy & 70 & 46.7 \\
\hline Girl & 80 & 53.3 \\
\hline \multicolumn{3}{|l|}{ Grade } \\
\hline $7^{\text {th }}$ grade & 31 & 20.7 \\
\hline $8^{\text {th }}$ grade & 49 & 32.7 \\
\hline $9^{\text {th }}$ grade & 31 & 20.7 \\
\hline $10^{\text {th }}$ grade & 39 & 26.0 \\
\hline
\end{tabular}

Table 2. Perceptions on Bullying

\begin{tabular}{|c|c|c|c|c|c|c|c|c|}
\hline Scenarios & & No & & nsure & & Yes & Mean & Description \\
\hline $\begin{array}{l}\text { Q. Do you think this student is getting } \\
\text { bullied? }\end{array}$ & $\mathrm{f}$ & $\%$ & $\mathrm{f}$ & $\%$ & $\mathrm{f}$ & $\%$ & & \\
\hline $\begin{array}{l}\text { 1.1 A student obtaining a hit kicked and } \\
\text { punched from his/her classmates. }\end{array}$ & 6 & $4 \%$ & 32 & $21.30 \%$ & 112 & $74.70 \%$ & 2.70 & Yes \\
\hline $\begin{array}{l}2.1 \text { A repeated act of stealing by students } \\
\text { on one's own belonging }\end{array}$ & 7 & $4.70 \%$ & 46 & $30.70 \%$ & 97 & $64.70 \%$ & 2.6 & Yes \\
\hline $\begin{array}{l}\text { 3.1. Summoned with mean names and } \\
\text { taunted by classmates. }\end{array}$ & 10 & $6.70 \%$ & 15 & $10 \%$ & 125 & $83.30 \%$ & 2.76 & Yes \\
\hline $\begin{array}{l}\text { 4.1. A student sustains disputing with } \\
\text { his/her mates in school. }\end{array}$ & 25 & $16.70 \%$ & 58 & $38.70 \%$ & 67 & $44.70 \%$ & 2.28 & Unsure \\
\hline $\begin{array}{l}\text { 5.1. Intentionally a student is neglected } \\
\text { by classmates }\end{array}$ & 23 & $15.30 \%$ & 67 & $44.70 \%$ & 60 & $40 \%$ & 2.24 & Unsure \\
\hline $\begin{array}{l}\text { 6.1. A student wishes to consume } \\
\text { lunchtime solely }\end{array}$ & 67 & $44.70 \%$ & 57 & $38 \%$ & 26 & $17.30 \%$ & 1.71 & Unsure \\
\hline $\begin{array}{l}\text { 7.1. A student's belongings are corrupted } \\
\text { intentionally by other students in school. }\end{array}$ & 14 & $9.30 \%$ & 25 & $16.70 \%$ & 111 & $74 \%$ & 2.64 & Yes \\
\hline $\begin{array}{l}\text { 8.1. A student continues receiving } \\
\text { offensive communications and social } \\
\text { media posts from someone in school. }\end{array}$ & 7 & $5 \%$ & 12 & $8 \%$ & 131 & $87.30 \%$ & 2.82 & Yes \\
\hline $\begin{array}{l}\text { 9.1. A student's classmates continue } \\
\text { circulating stories that are not valid. }\end{array}$ & 3 & $2 \%$ & 10 & $6.70 \%$ & 137 & $91.30 \%$ & 2.89 & Yes \\
\hline $\begin{array}{l}\text { 10.1. A student continues receiving } \\
\text { threats from other students in school. } \\
\text { 11.1. A student continues landing }\end{array}$ & 6 & $4 \%$ & 21 & $14 \%$ & 123 & $82 \%$ & 2.78 & Yes \\
\hline $\begin{array}{l}\text { towards bickering with the teacher and } \\
\text { usually gets the blame for things not } \\
\text { perpetrated.. }\end{array}$ & 11 & $7.30 \%$ & 23 & $15.30 \%$ & 116 & $77.30 \%$ & 2.7 & Yes \\
\hline $\begin{array}{l}\text { 12.1. A student's classmates are } \\
\text { continuously pressing on copying the } \\
\text { homework. }\end{array}$ & 26 & $17.30 \%$ & 69 & $46 \%$ & 55 & $36.70 \%$ & 2.19 & Unsure \\
\hline Overall Mean & & & & & & & & Yes \\
\hline 2- UNSURE 3-YES & & & & & & & & \\
\hline
\end{tabular}

post-traumatic stress disorder symptoms. Bullying is a destructive act by a person, normally revolving over time that deliberately harms another individual, producing distress (Limber at al., 2012).

Bullying can either be immediate or implied. Direct bullying occurs when the tyrant targets the sufferer personally, such as taunting, intimidating, beating, or stealing. On the other hand, indirect bullying is when the bully does not undeviatingly reach the victim, such as news spreading or social withdrawal but creates damage to that person emotionally (Teenink, 2011).

Bullying theory is not new, and in recent years it starts to surge. A significant increase in some studies of bullying among high school students is evident at school in mass media, 
Table 3. Perceptions on Bullying

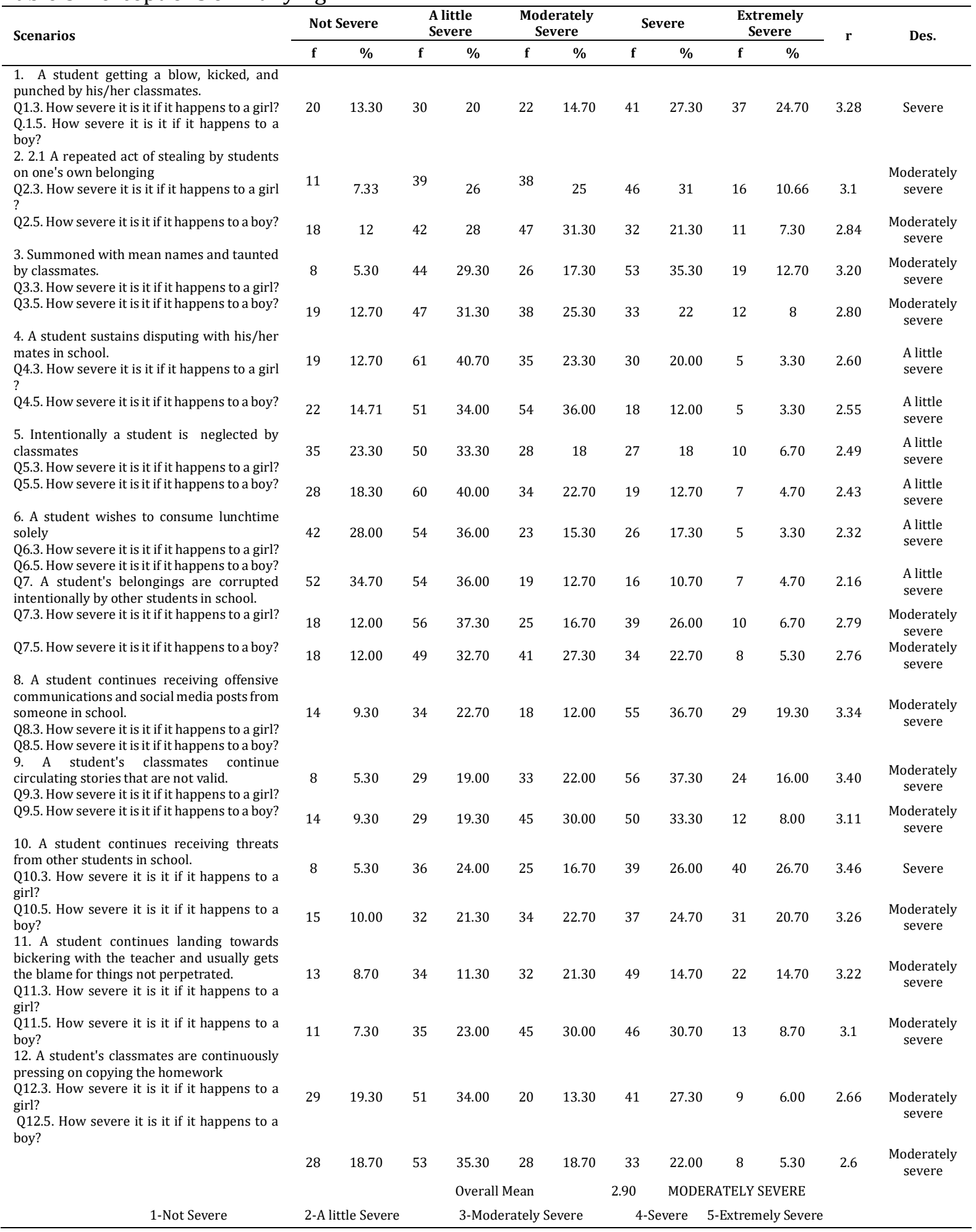

where it continues to receive attention from researchers, parents, students, and educators (Turkmen, et al., 2013). Research has also indicated that bullying destroys the lives of individuals affecting their self -esteem, and confidence (Langcamon \& Enderez, 2014).
The study aims to determine the perception of bullying substantiating the prevalence underlying its existence among junior high school students of BiPSU. 


\section{METHOD}

\subsection{Design}

The researchers used descriptive research design through a random sampling technique to determine the prevalence of bullying among secondary students. In descriptive research plainly describes a demographic segment's nature, not noticing why a phenomenon occurs. It represents the subject of the study without covering the whys (Question Pro, 2002). In the primary stages of a study, it might not be easy to form a hypothesis, especially when there is no standing literature in the area. In these conditions planning an experiment would be immature, as the question of interest is not ultimately distinctively defined as a hypothesis. A researcher will often begin with a non-experimental method, such as a descriptive study, to gather more information about the topic before working out an experiment or correlational study to direct a specific conclusion (Lumenlearning, 2011).

\subsection{Respondents}

The study respondents were 150 or $60 \%$ of the enrolled junior high school students of BiPSU and randomly chosen as they were approached in the Laboratory Junior High School premises during and after class. An elaboration of the study was briefly discussed with the participants or respondents to understand the study better. There are ten who refused to participate and were left respected of their rights. None of the students dropped their participation in the research. The respondents were given questionnaires and voluntarily answered. The study subjects are students of grades 7 to grade 10 in the current school year. Grade 7- 40 students, Grade 8-40 students, Grade 9-37 students, and Grade 10-33 students.

\subsection{Instrument}

The study made use of one survey with two instruments. Questions of qualitative in nature about the school is found in Part 1 of the survey, while the data on bullying specific scenarios are in Part 2 of the survey. In Part 1 , demographic questions were answered by the participants, while in Part 2, there are 12 bullying scenarios from Maunder, et al. (2010), specifying bullying categories.

\subsection{Data Collection}

Prior to data collection, research proposal was submitted to the institutional ethics committee for the approval to conduct the study. Afterwards, transmittal letters were sent to the concerned authorities for permission and approval to conduct the study. Consent forms were provided to the parents through their class advisers, assuring confidentiality of the process. During the data collection, consents were secured, explained the study's purpose to the respondents, and their involvement with assurance that the data would not be used against them and treated with confidentiality. The data were collected using survey questionnaires among respondents who voluntarily participate without any hesitation. The study is conducted the classroom. After retrieval of questionnaires, data analysis and interpretation followed. The study results are in tables, and narrative descriptions reflect the study variables.

\subsection{Analysis}

The Filled-in questionnaires underwent checking for completeness and consistency of the responses. The data were tabulated and analyzed using the Statistical Package for the Social Sciences (SPSS)- Descriptive Statistics' Frequency, Percentile and Central Tendency where variables are statistically analyzed.

\subsection{Ethical Clearance}

The ethical was performed to participant through informed consent.

\section{RESULT}

From 160 students, 150 participated in the survey with a $93.7 \%$ response rate and questionnaires were analyzed. The analysis and interpretation of data are following the questions about the problem under investigation.

\subsection{Profile of the Respondents}

In Table 1, Grade 8 level has the highest percentage among the research respondents, gaining $32.7 \%$ of the respondents' total number. They were followed by grade 10 , which accounts for $26.0 \%$, and minority accounts for steps 7 and 9 with $20.7 \%$. During the data collection, more Grade 8 students 
Table 4. Prevalence on Bullying

\begin{tabular}{|c|c|c|c|c|c|c|c|c|c|c|c|c|}
\hline & \multicolumn{2}{|c|}{ Never } & \multicolumn{2}{|c|}{$\begin{array}{l}\text { Once in a } \\
\text { semester }\end{array}$} & \multicolumn{2}{|c|}{ Weekly } & \multicolumn{2}{|c|}{$\begin{array}{c}\text { Numerous } \\
\text { occasions in a } \\
\text { week }\end{array}$} & \multicolumn{2}{|c|}{ Utmost days } & \multirow[t]{2}{*}{ Mean } & \multirow[t]{2}{*}{ Des. } \\
\hline & $f$ & $\%$ & $f$ & $\%$ & $f$ & $\%$ & $f$ & $\%$ & $f$ & $\%$ & & \\
\hline $\begin{array}{l}\text { 1. A student obtaining a hit kicked and punched from } \\
\text { his/her classmates. } \\
\text { Q1.2. How frequently do you learn about this occurrence to } \\
\text { a girl in school? }\end{array}$ & 57 & 38 & 40 & 26.70 & 21 & 14 & 19 & 12.70 & 13 & 8.70 & 2.27 & 2 \\
\hline $\begin{array}{l}\text { Q1.4. How frequently do you learn about this occurrence to } \\
\text { a boy in school? }\end{array}$ & 31 & 20.70 & 42 & 28 & 36 & 24 & 25 & 16.70 & 16 & 10.70 & 2.68 & 4 \\
\hline $\begin{array}{l}\text { Q1.6. How often do you obtain a hit, a kick, and punch from } \\
\text { your classmates? }\end{array}$ & 91 & 60.70 & 32 & 21.30 & 7 & 4.70 & 8 & 5.30 & 12 & 8.00 & 1.78 & 1 \\
\hline $\begin{array}{l}\text { 2. A repeated act of stealing by students on one's own } \\
\text { belonging } \\
\text { Q2.2. How frequently do you learn about this occurrence to } \\
\text { a girl in school? }\end{array}$ & 36 & 24 & 54 & 36.00 & 28 & 18.70 & 22 & 14.70 & 10 & 6.70 & 2.44 & 2 \\
\hline $\begin{array}{l}\text { Q2.4. How frequently do you learn about this occurrence to } \\
\text { a boy in school? }\end{array}$ & 38 & 25.30 & 41 & 27.30 & 23 & 26.00 & 39 & 26.00 & 9 & 6.00 & 2.6 & 2 \\
\hline Q2.6. How frequent were your belongings stolen? & 68 & 45.30 & 43 & 28.70 & 14 & 9.30 & 18 & 12.00 & 7 & 4.70 & 2.02 & 2 \\
\hline $\begin{array}{l}\text { 3. Summoned with mean names and taunted by classmates.. } \\
\text { Q3.2. How frequently do you learn about this occurrence to } \\
\text { a girl in school? }\end{array}$ & 21 & 14 & 39 & 26 & 31 & 20.70 & 30 & 20.00 & 29 & 19.30 & 3.046 & 4 \\
\hline $\begin{array}{l}\text { Q3.4. How frequently do you learn about this occurrence to } \\
\text { a boy in school? }\end{array}$ & 16 & 10.70 & 28 & 18.70 & 31 & 20.70 & 37 & 24.70 & 38 & 25.30 & 3.35 & 3 \\
\hline $\begin{array}{l}\text { Q3.6. How frequent do you get summoned with mean } \\
\text { names by your classmates? }\end{array}$ & 53 & 35.30 & 28 & 18.70 & 23 & 15.30 & 21 & 14.00 & 25 & 16.70 & 2.58 & 2 \\
\hline $\begin{array}{l}\text { 4. A student sustains disputing with his/her mates in } \\
\text { school. } \\
\text { Q4.2. How frequent does this happen to a to a girl in your } \\
\text { school? }\end{array}$ & 18 & 12.00 & 47 & 31.30 & 38 & 25.30 & 26 & 17.30 & 21 & 14.00 & 2.88 & 4 \\
\hline $\begin{array}{l}\text { Q4.4. How frequent does this happen to a to a boy in your } \\
\text { school? }\end{array}$ & 23 & 15.30 & 46 & 30.70 & 29 & 19.30 & 31 & 20.70 & 21 & 14.00 & 2.83 & 4 \\
\hline $\begin{array}{l}\text { Q4.6. How frequent do you get summoned with your } \\
\text { friends at school? }\end{array}$ & 55 & 36.70 & 36 & 24.00 & 18 & 12.00 & 27 & 18.00 & 14 & 9.30 & 2.39 & 4 \\
\hline $\begin{array}{l}\text { 5. Intentionally a student is neglected by classmates } \\
\text { Q5.2. How frequent this incident happens to a girl in school? }\end{array}$ & 53 & 35.30 & 42 & 28.00 & 25 & 16.70 & 19 & 12.70 & 11 & 7.30 & 2.28 & 2 \\
\hline $\begin{array}{l}\text { Q5.4. How frequent this incident happens to a boyl in } \\
\text { school? }\end{array}$ & 45 & 30.00 & 40 & 26.70 & 30 & 20.00 & 2 & $\begin{array}{c}17.30 \\
\%\end{array}$ & 9 & 6 & 2.38 & 2 \\
\hline Q5.6. How frequent were you intentionally neglected? & 71 & 47.30 & 31 & 20.70 & 20 & 13.30 & 16 & 10.70 & 12 & 8.00 & 2.07 & 2 \\
\hline 6. A student wishes to consume lunchtime solely. & 57 & $38 \%$ & 34 & $22.7 \%$ & 22 & $14.7 \%$ & 13 & $8.7 \%$ & 24 & $16 \%$ & 2.42 & 2 \\
\hline Q6.2. How frequent does this happen to a girl in school? & 62 & 41.30 & 35 & 23.30 & 27 & 18.00 & 12 & 8 & 14 & $9.3 \%$ & 2.2 & 2 \\
\hline $\begin{array}{l}\text { Q6.4. How frequent does this happen to a boty in school? } \\
\text { Q6.6. How frequent are you eating lunch alone? }\end{array}$ & 75 & 50.00 & 27 & 18.00 & 23 & $15.3 \%$ & 6 & $10.7 \%$ & 9 & $6 \%$ & 2.04 & 2 \\
\hline 7. A student's belongings are corrupted intentionally by & 42 & 28.00 & 54 & 36.00 & 16 & 10.70 & 29 & 19.30 & 9 & 6.00 & 2.39 & 2 \\
\hline \multicolumn{13}{|l|}{$\begin{array}{l}\text { other students in school } \\
\text { Q7.2. How frequent does this happen to a girl in school? }\end{array}$} \\
\hline $\begin{array}{l}\text { Q7.4. How frequent does this happen to a boy in school? } \\
\text { Q7.6. How frequent were your belongings corrupted at } \\
\text { school? }\end{array}$ & 65 & 43.30 & 45 & 30.00 & 18 & 12.00 & 17 & 11.30 & 5 & 3.00 & 1.99 & 2 \\
\hline 8. A student continues receiving offensive communications & 22 & 14.74 & 40 & 26.70 & 43 & 28.70 & 29 & 19.30 & 16 & 10.70 & 2.84 & 4 \\
\hline $\begin{array}{l}\text { and social media posts from someone in school. } \\
\text { Q8.2. How frequent does this happen to a girl in school? }\end{array}$ & 39 & 26.00 & 46 & 30.70 & 31 & 20.70 & 25 & 16.70 & 9 & 6.00 & 2.43 & 3 \\
\hline $\begin{array}{l}\text { Q8.4. How frequent does this happen to a boy in school? } \\
\text { Q8.6. How frequently do you receive offensive texts and } \\
\text { social media posts in school? }\end{array}$ & 99 & 66.00 & 22 & 14.70 & 11 & 7.30 & 10 & 6.70 & 8 & 5.30 & 1.70 & 1 \\
\hline $\begin{array}{l}\text { 9. A student's classmates continue circulating stories that } \\
\text { are not valid }\end{array}$ & 19 & 12.70 & 44 & 29.30 & 28 & 18.70 & 36 & 24.00 & 23 & 15.30 & 3 & 3 \\
\hline \multicolumn{13}{|l|}{ Q9.2. How frequent does this happen to a girl in school? } \\
\hline $\begin{array}{l}\text { Q9.4. How frequent does this happen to a boy in school? } \\
\text { Q9.6. How frequent have your classmates circulate rumors } \\
\text { about you? }\end{array}$ & 54 & 36.00 & 53 & 35.30 & 17 & 11.30 & 17 & 11.30 & 9 & 6.00 & 2.16 & 2 \\
\hline \multirow{2}{*}{$\begin{array}{l}\text { 10. A student continues receiving threats from other } \\
\text { students in school. }\end{array}$} & 40 & 26.70 & 42 & 28.00 & 24 & 16.00 & 28 & 18.70 & 16 & 10.70 & 2.58 & 2 \\
\hline & 33 & 22.00 & 48 & 32.00 & 27 & 18.00 & 30 & 20.00 & 12 & 8.00 & 2.6 & 2 \\
\hline $\begin{array}{l}\text { Q10.2. How frequent does this happen to a girl in school? } \\
\text { Q10.4. How frequent does this happen to a boy in school? } \\
\text { Q10.6. How frequent are you threatened at school? }\end{array}$ & 84 & 56.00 & 34 & 22.70 & 16 & 10.70 & 10 & 6.70 & 6 & 4.00 & 1.8 & 1 \\
\hline \multirow{3}{*}{$\begin{array}{l}\text { 11. A student continues landing towards bickering with the } \\
\text { teacher and usually gets the blame for things not } \\
\text { perpetrated } \\
\text { Q11.2. How frequent does this happen to a girl in school? } \\
\text { Q11.4. How frequent does this happen to a boy in school? } \\
\text { Q11.6. How frequent were you in trouble with the teacher } \\
\text { for things you have not doen? }\end{array}$} & 44 & 29.30 & 47 & 31.30 & 17 & 11.30 & 38 & 25.30 & 4 & 2.70 & 2.40 & 2 \\
\hline & 43 & 28.70 & 50 & 33.30 & 20 & 13.30 & 24 & 16.00 & 13 & 8.70 & 2.42 & 2 \\
\hline & 87 & 58.00 & 33 & 22.00 & 21 & 14.00 & 9 & 6.00 & 0 & 0.00 & 1.68 & 1 \\
\hline \multirow{4}{*}{$\begin{array}{l}\text { 12. A student's classmates are continuously pressing on } \\
\text { copying the homework. } \\
\text { Q12.2. How frequent does this happen to a girl in school? } \\
\text { Q12.4. How frequent does this happen to a boy in school? } \\
\text { Q12.6 How frequent are you pressured on giving a copy of } \\
\text { your work to your classmates? }\end{array}$} & 14 & 9.30 & 38 & 25.30 & 21 & 14.00 & 34 & 22.70 & 43 & 28.70 & 3.36 & 4 \\
\hline & 18 & 12.00 & 33 & 22.00 & 21 & 14.00 & 30 & 20.00 & 48 & 32.00 & 3.38 & 4 \\
\hline & 35 & 23.30 & 34 & 22.70 & 31 & 20.60 & 29 & 19.30 & 21 & 14.00 & 2.79 & 4 \\
\hline & & Over & Mean & 2.47 & & & & & & & & 2 \\
\hline 1-Never & orty & a term & & ce a week & Sever & me a week & & Most day & & & & \\
\hline
\end{tabular}

were available and took part in the data gathering.

\subsection{Perceptions on Bullying}

As to the perceptions of bullying, Table 2 revealed an average weighted mean of 2.52 , which showed a "yes, "which signified students' awareness in the scenarios. Students already knew what bullying all is about. Spreading rumors or suppositions gained the highest percentage, with 91.3\% being considered a form of bullying. The constant argument with friends got the lowest rate of $44.7 \%$ was also a form of bullying as perceived by the respondents.

\subsection{Perception on Bullying as to the Degree of Severity}

Table 3 showed, the average weighted mean on bullying perception as to severity is 2.9 
and described as "Moderately Severe," as revealed in Table 3. The result showed that most of the respondents who answered once or twice a term gained $34 \%$ as the highest percentage. About gender involvement in terms of the severity of bullying was higher on girls with $34 \%$ compared to boys with $32.7 \%$. While teacher involvement in altercations with classmates regardless of gender was described by the respondents as extremely serious at $22 \%$.

\subsection{Prevalence on Bullying}

A general weighted mean on the prevalence of bullying is 2.47 occurring once or twice a term at school. The respondents provided answers to questions on bullying, but none of them experienced being bullied.

\section{DISCUSSION}

\subsection{The Knowledge of Feeding in Stunting Toddler's Mother in Work Area Public Health Center Tambak Wedi Surabaya}

Females represent most of the respondents at $53.3 \%$, where boys are only $46.7 \%$, and 33 $\%$ account for most of the respondents, which is 13 . These values relate to the total enrolled students of junior high school in BiPSU.

Over the previous two decades, women have made significant educational improvement. Females are more inclined than males to attend college after high school and are as reasonable to graduate with a postsecondary degree (National Center for Education Statistics, 1995). The early and more vital step to fighting and avoiding bullying is being informed that it is an issue and paying attention to warning signs (Loveless, 2019)

Moderate to severe bullying varies from mild bullying. It reflects an imperative method that comprises recurrent and persistent negative actions toward one or more individual(s), which suggest a perceived power asymmetry and develop a moody atmosphere. Bullying becomes moderate to severe when abuse increases in frequency and personalization; the key is thought to injure or break (Namie, 2011).

The data on prevalence of bullying, signified a rare occurrence of bullying at school as perceived by the respondents in BiPSU. School partnerships can be established with community members that influence students to better behavior or motivate them to find help when they call for it. By adopting various bullying approaches, schools can position themselves to handle bullying before it gets tragic (Loveless, 2019).

\section{CONCLUSION}

The perception and prevalence of bullying among junior high school students have opened an opportunity to improve the school's policies addressing such kind and increase the awareness of its existence. The majority of the respondents have not experienced bullying. Students think that bullying at school happens once or twice a term. Understanding bullying is vital in recognizing it as a problem, decreasing nonconfrontation by individuals rather than ignoring it. Addressing the dilemma of bullying lessens infliction and distress among youths. The schools can better position themselves by adopting multiple strategies to address bullying and partnerships with the local government to conduct programs to inspire students and engage in healthful activities enthusiastically. Students' perception of bullying is significant than its prevalence. Students have increased knowledge and awareness of bullying. However, though less notable than the perception, these pervasion results are meaningful because students' reflection in bullying is distinguished.

\section{CONFLICT OF INTEREST}

The authors declare that there is no conflict of interest

\section{REFERENCES}

Anderson, J. (2011). National Study Finds Widespread Sexual Harassment of Students in Grades 7 to 12 . Diambil kembali dari The New York Times.

Langcamon, L., \& Enderez, D. (2014). Bullying, Is Still A Big Problem. Diambil kembali dari https://www.slideshare.net/skylarkXo Xo21/research-study-about-bullying

Limber, S., Wang, W., Masiello, M., \& Olweus, D. (2018). Evaluation of the Olweus Bullying Prevention Program: A large 
scale study of U.S. students in grades 311. Research Gate.

Loveless, B. (2021). Bullying Epidemic: Facts, Statistics and Prevention. Diambil kembali dari https://www.educationcorner.com/bull ying-facts-statistics-andprevention.html

Lumen Learning. (2011). Descriptive Research. Diambil kembali dari https://courses.lumenlearning.com/w mopen-psychology/chapter/outcomeapproaches-to-research/

Maunder, R., Tattersall, A., \& Harrop, A. (2010). Pupil and staff perceptions of bullying in secondary schools: Comparing behavioural definitions and their perceived seriousness. Researchgate. doi:10.1080/00131881.2010.504062

Namie, G. (2011). Moderate to Severe Bullying. Diambil kembali dari https://www.safeathopkins.org/workpl ace-bullying/moderate-to-severebullying/

National Bullying Prevention Center. (2016). Bullying statistics. Diambil kembali dari https://www.pacer.org/bullying/resou rces/stats.asp
National Center for Education Statistics. (1995, November). The Educational Progress of Women. Diambil kembali dari https://nces.ed.gov/pubs/96768.pdf

Question Pro. (2012). Descriptive Research: Definition, Characteristics, Methods, Examples and Advantages. Diambil kembali dari https://www.questionpro.com/blog/de scriptive-research/

Rigby, K., \& Johnson, K. (2015). THE PREVALENCE AND EFFECTIVENESS OF ANTI-BULLYING STRATEGIES EMPLOYED IN AUSTRALIAN SCHOOLS. Diambil kembali dari University of South Australia.

Teen Ink. (2011). Bullying in School. Diambil kembali dari https://www.teenink.com/opinion/sch ool_college/article/331645/Bullying-inSchool/

Turkmen, D. N., Dokgoz, M. H., Akgoz, S., Eren, B., Vural, H., \& Polat, H. (2013). Bullying among High School Students. Diambil kembali dari https://www.ncbi.nlm.nih.gov/pmc/art icles/PMC3865123/ 